The 16th Economic International Conference

New Challenges and Opportunities for the Economy 4.0, May 7-8th, 2020, Suceava, Romania

\title{
The Need to Improve Performance Indicators Used in the Global Evaluation of the Company
}

\author{
Cristina IACOBAN, Svetlana MIHAILA, Elena HLACIUC \\ https://doi.org/10.18662/lumproc/ncoe4.0.2020/12
}

How to cite: Iacoban, C., Mihaila, S., \& Hlaciuc, E. (2020). The Need to Improve Performance Indicators Used in the Global Evaluation of the Company. In C. Nastase (vol. ed.), Lumen Proceedings: Vol. 13. 16th Economic International Conference NCOE 4.02020 (pp. 130-138). Iasi, Romania: LUMEN Publishing House.

https://doi.org/10.18662/lumproc/ncoe4.0.2020/12 


\title{
The Need to Improve Performance Indicators Used in the Global Evaluation of the Company
}

\author{
Cristina IACOBAN11, Svetlana MIHAILA2, \\ Elena HLACIUC 3
}

\begin{abstract}
The purpose of this paper is to identify the most relevant performance indicators that need to be improved in order to assess as objectively as possible the overall value of the company. In order to achieve the proposed goal we set the following objectives: objective 1 - establishing the main performance indicators according to the company's field of activity, objectives, mission and vision of the company and objective 2 - identifying the most relevant indicators established by achieving objective 1, which need to be improved as a result of the evolution of technological and economic progress that is currently being made.

The obtained results consist in offering viable solutions regarding the most realistic evaluation of the global value of an economic entity by improving the economic-financial indicators used.

The results can be of real use for all companies, regardless of the field of activity, which want a more objective global assessment of their values, for shareholders or associates, for employees, for creditors and all commercial participants, but also for rating agencies.
\end{abstract}

Keywords: Performance evaluation; performance indicators; profitability.

\footnotetext{
1 "Stefan cel Mare" University of Suceava, Suceava, Romania, iacobancristina@yahoo.com.

2 Academy of Economic Studies of Moldova, Chisinau, Republic of Moldova, sv mihaila@yahoo.com.

3 "Stefan cel Mare" University of Suceava, Suceava, Romania, elena.hlaciuc@,usm.ro. 


\section{Introduction}

Measuring the financial performance of companies in the decisionmaking process is one of the most important topics at the present time in the financial and economic field. The added economic value is among the most important criteria for measuring financial performance. This can be described as the success of a company and its activities. Thus, the added economic value and the financial performance are closely linked. The approaches to the added economic value aim to provide a clearer indication of the contribution to performance.

The added economic value is a measure of the financial performance of an entity that has a fairly long history of application in economics. This was considered to be an increase in the wealth of the company's shareholders. The added economic value is a useful tool because it emphasizes the capital management, as well as the profit management. Therefore, research on this topic is welcome.

\section{Problem Statement}

Due to the ample evolutions of the last ten years in the corporate world, managers and investors were looking for an economic framework to better reflect the value and profitability of their company. The accounting instruments that have been used so far are not enough to meet the challenge generated by the market and efficient capital owners.

Currently, the business environment faces a lot of challenges that have a positive or negative impact on the companies' performance. Thus, the business world is influenced by various factors such as globalization, intense competition, high costs, deregulation, exchange rates or the volatility of the interest rate. All these challenges determined the managers to turn all their attention towards the creation of value, as the main objective of any company is the creation of value, and the main role of managers is that of maximizing the wealth of shareholders through effective granting of the resources.

\section{Aims of the research}

The main objectives are focused on analysing the impact of the added economic value on the decisions of managers and investors in the case of companies listed on the stock exchange. In addition to this, other objectives are oriented towards: presenting the theoretical meanings of the 
concept of added economic value (EVA); determining the advantages and disadvantages of using the added economic value as a tool for measuring performance.

\section{Research Methods}

The purpose of our research consists in the study and theoretical and practical argumentation of the added economic value for an economic entity, emphasising the importance and the actuality of the theme.

\section{Findings}

\subsection{Financial theories that approach the creation of value}

Over time, the value created for the shareholders is determined, using traditional methods, either by standard countable indicators such as profits or cash flows from the operations that were carried out, or by the financial indicators that are found in the financial situations such as the profitability rates (ROCE, ROE, and ROA) or the earnings per share (EPS). This financial information is used by managers, shareholders and other interested parties to evaluate the current performance and also to predict the future performance of an economic entity [12]. But, as we well know, the financial situation may not have anything to do with the real situation of a company. Therefore, managers and investors have been looking for years in a row for much more efficient indicators to measure the shareholders' wealth. A summary close to the economic-financial practice is the one addressed in figure 1 [3].

Under these conditions, several researchers have suggested new performance indicators, modern indicators, to replace the classic ones in measuring the financial performance of the economic entity. Thus, one of these new indicators is the added economic value (EVA - Economic Valued Added), representing a management instrument that encompasses both profitability and growth objectives, indicating the surplus value created by entities from the activity carried out, or the performance of an investment" [2].

The added economic value is a model introduced by the American economist G. Bennett Stewart, who is also one of the founders of the SternStewart \& Co company. It states that "EVA makes the managers rich only if the managers make shareholders rotten rich". By publishing "The Quest for Value: The EVA-Management Guide" in 1982, Bennett Stewart laid the 
foundation for the most successful performance measurement tool used by companies around the world [14].

Figure 1. The main indicators for measuring values

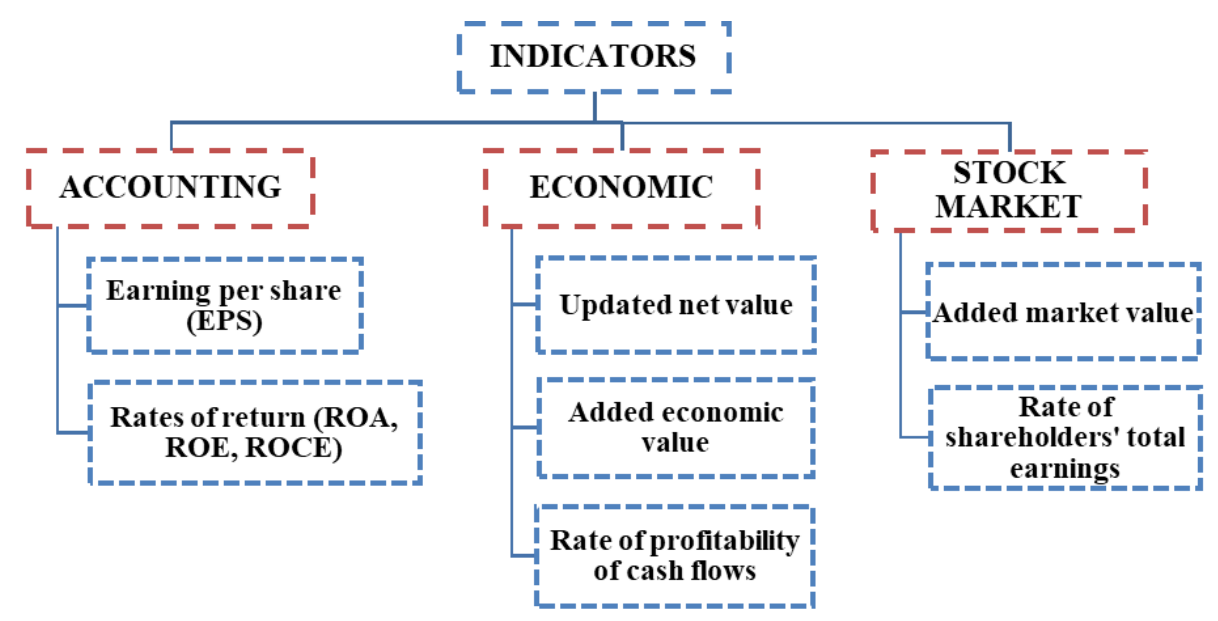

The added economic value is appreciated as being an indicator that is "superior to the countable rates as a measure of value creation because it recognizes the cost of capital and, consequently, the level of risk of a company's operations. By comparison, traditional rates - such as all rates of return (ROE, ROA, ROCE) - do not indicate the economic return of a company because they are based on historical values of assets, which in turn are distorted by inflation and other factors" [18].

The added economic value is a registered trademark of the consulting company from New York - Stern-Stewart \& Co. A large part of the success of this indicator is due to the marketing activities that refer to the promotion and implementation of the economic value added by the Stert Stewart company, but the indicator is justified by financial theory and is related to the evaluation principles [9]. As a result, the added economic value is recognized as one of the most representative instruments for measuring managerial performance through the value created for shareholders.

Although the concept of added economic value was first applied in 1990, many years before, the economists applied a similar concept economic profit or residual profit. Thus, EVA is a modified version of the residual profit. The difference between the two concepts is the purpose of use, where the residual profit is used to serve the managers as a tool for evaluating the internal performance of the company and its various departments, while the added economic value is used to serve the 
shareholders more as a tool for communicating information on the company's performance.

At an international level, more authors have developed the concept of added economic value and value creation, after it was presented in Bennett Stewart's book. These include economists Joel Stern and John Shiely, who have made an important contribution to the development of the subject through "The EVA Challenge", and other authors such as David Yung and Stephen O'Byrne have tended more towards the technical part of the implementation of the added economic value [6]. At a national level, the ones who addressed the concept of performance by creating value and of the EVA indicator calculation method were Bostan et al. [4] [5].

Stewart considers that the added economic value is the best measure to determine the internal and external performance and that this measure should replace the previous accounting measures, such as the earnings and capital from operations. This company claims that earnings per earnings per share, the rate of return on shareholders' equity and the rate of return on investment should be set aside and, instead, the added value should be used, which determines the share price and is a basis for measuring performance. In his 1994 speech, Stewart said that "the added economic value is the best measure for capital growth and it works better than other measures that are based on an accounting to determine the changes of the shareholder's wealth value" [15].

In theory, the added economic value responds to two fundamental financial principles:

- "the first principle - any company should have as its goal the enrichment of its owners (shareholders);

- the second principle - the value of the company depends on how much the investors want the future profits to exceed the cost of capital" [17]. On this basis, the added economic value can be assimilated to a residual income of the shareholder. As a result, the size of the added economic value is what counts at a given moment, because it is not, in fact, an indicator of the value of the enterprise. At best, the current performance is shown in the stock market.

The added economic value is the most advanced tool for measuring the business performance based on the principle of value-based management. This is due to a relatively simple approach compared to other evaluation methods, as well as to the possibility of complex application of this indicator in the management system.

In conclusion, the added economic value is important in the future, as its evolution reflects an increase or not in the wealth of the shareholders. 


\subsection{The advantages of added economic value versus traditional performance evaluation methods}

Despite the importance of traditional indicators of accounting and their widespread use by accounting professionals, practitioners, financial professionals, and other groups of users, these indicators present more disadvantages, such as [11]:

- The incapacity for traditional indicators of accounting to determine the real economic value of the wealth of the owner;

- The basis being on determined accounting information in accordance with the principle of historical cost;

- Inability to detect failures and bankruptcy to which the company may be exposed;

- Inability to help current and potential investors to make prudent investment decisions

Based on the above, it has become necessary for new evaluation indicators capable of overcoming the disadvantages of traditional methods of accounting, which can be trusted to provide additional information that is more relevant and useful to decision making factors. This has led to the emergence of new indicators, the most important of which is the added economic value. The company that has implemented the added economic value states that the most important benefit of this indicator is that it adjusts the reported accounting results to eliminate the distortions encountered in measuring real economic performance.

Traditional performance measures, such as rates of return or earnings per share, are criticized because they are deficient. These measures are one-dimensional and thus improper for fully evaluating the strategic accountability of firms, the strategic results and the performances of firms. Also, traditional measures reflect only the past performance, not the future performance. Moreover, the added economic value corresponds more to the company's objectives than the return on investment (ROI), as this helps to overcome the objective of incongruity that exists between the manager and the company, which cannot be solved using ROI [1].

Traditional accounting measures ignore the differences in risks assumption between companies in search of profit [10]. Managers tend to manipulate reported accountable profits for their own benefit and choose alternative accounting procedures within the GAAP. Some common techniques involve switching between inventory policies, changing depreciation methods and provisioning expenses.

Traditional profits, such as earnings per share and the return on equity, are among the most frequently used performance measures, being 
criticized for not taking into account the total cost of capital and for the influence induced by the conventions of the accounting of commitments, while the added economic value, calculated by taking into account the difference between the operating profits after taxation and the total cost of capital, is treated as a measure of the real return of a firm.

In addition, the added economic value allows its users to assess whether the return on invested capital exceeds the cost measured by the profitability of alternative uses of the capital. As a result, the management can do different things to create value for the business. Regardless of what the management does, if the value is created, this will be reflected, in the end, in the amount of the added economic value [16].

The adoption of added economic value at the level of companies has steadily increased, as managers have become dissatisfied with the standard of countable measures that do not provide information useful in terms of decision making. An increasing number of enterprises have an additional set of indicators as performance measurement tools (in integrated reporting), in order to improve their understanding and their capacity to achieve profitability [7].

\section{Discussions}

Traditional performance measures have some shortcomings in the direction of maximizing the shareholders' wealth, ignoring the cost of capital. Such measures do not have an effective mechanism for determining whether the achievement of these objectives creates value for the shareholders. Even if a company generates net incomes and a large ROI, it is possible that it will no longer be able to contribute to the creation of value for shareholders, provided that the profits do not exceed the amounts requested, which the shareholder could earn by investing in other securities with comparable risk.

The added economic value is a tool for complexly and completely measuring performance in the light of the fact that this indicator combines both information of an accounting and economic nature [13]. Compared to its traditional or classic instruments of performance, which are based only on the accounting information, the added economic value implies making adjustments to accounting information, thus gaining an economically sustainable character. Given the fact that it is not a victim of accounting manipulations, "the added economic value is a healthy managerial criterion, able to lead to an efficient use of all the company's resources and, through this, to the generation of gains superior to the incurred costs" [8]. 
In conclusion, it is very important for companies to identify and choose that method, which measures the best and most accurately the value of the company, without being biased towards third parties. The selection of an appropriate measure is critical to the success of the company.

\section{Conclusions}

The added economic value should be disclosed to its investors or shareholders, which would contribute to attracting new investors, and the capital would increase by avoiding the debt. Traditional methods are not enough to reflect real financial performance. Consequently, methods such as added economic value are needed to measure the economic profit which is the best in measuring management efficiency. The great plus that the added economic value in comparison with the traditional methods of measurement brings is the attention paid to the cost of the invested capital because the capital invested in a company comes with associated inherent costs. Regardless of the form of invested capital, either equity or debt, the one who provides the funds expects a corresponding return. However, the ultimate goal of any company is the creation of value for capital suppliers and that is why the added economic value is a decisive factor for the shareholders.

We consider that although the concept of added economic value brings with it a series of challenges in being understood, manipulated and implemented, the study shows that the use of this indicator brings added value to companies and sustainable and long-term development.

\section{Acknowledgement}

This work is supported by project POCU 125040, entitled "Development of the tertiary university education to support the economic growth - PROGRESSIO", co-financed by the European Social Fund under the Human Capital Operational Program 2014-2020

\section{References}

[1] Al Mamun A, Shazali AM. EVA as Superior Performance Measurement Tool, Modern Economy, nr. 3, 2012, 313 p.

[2] Balte; N, Minculete G. Raportările contabile anuale - sursa informațională privind aprecierea performanței financiare a entității economice. Studiu de caz: industria farmaceutică, CECCAR Business Magazine, nr. 2, 24-30 ianuarie 2017, $5 \mathrm{p}$. 
[3] Bogdan VD. Overall Performance - by Creating Value, Managementul Intercultural, nr. 2, 2014, 43 p.

[4] Bostan I, Grosu V. Contribution of balance scorecard model in efficiency of managerial control, Romanian Journal of Economic Forecasting; 2011.

[5] Bostan I, Mates D, Grosu V, Hlaciuc E, Socoliuc M, Iancu E. Implications of the EVA model use in the firm resources' performant allocation plan, Journal of Accounting and Management Information Systems; 2010; 9 (1).

[6] Ciora C. Analiza performanței prin creare de valoare. Bucureşti: Ed. Economică; 2013, 66 p.

[7] Cosmulese CG, Socoliuc M, Ciubotariu MS, Mihaila S, Grosu V. An empirical analysis of stakeholders' expectations and integrated reporting quality, Economic Research-Ekonomska Istraživanja, 2020.

[8] Ganea M. Crearea de valoare economică şi interdependenţele dintre aceasta şi indicatorii clasici de performanță, Revista Audit Financiar, nr. 12; 2014, 23 p.

[9] Grosu V, Anisie L, Hrubliak O, Ratsa A. Managerial accounting solutions: Lean Six Sigma application in the woodworking industry. A Practical aspect. Economic Annals-XXI; 2019, 176(3-4): 118-130.

[10] Grosu V., Socoliuc M., Hlaciuc E. Romanian enterprises behaviour in the process of improvement of economic and financial disclosure quality, Economic annals-XXI; 2017, pp. 63-69.

[11] Hanan Ali Al-Awawdeh, Sa'ad Abdul Kareem Al-Sakini. The Impact of Economic Value Added, Market Value Added and Traditional Accounting Measures on Shareholders' Value, International Journal of Economics and Finance; 2018, 10(10).

[12] Haque MR., Islam MF. Economic Value Addedas a measurement tool of financial performance: a case study of square pharmaceuticals limited, Journal of Science and Technology, 11; 2013, 17 p.

[13] Houle M. Economic Value Added, Honors Program of Liberty University; 2008, $11 \mathrm{p}$.

[14] Lee S, Kim WG. EVA, refined EVA, MVA, or traditional performance measures for the hospitality industry?, International Journal of Hospitality Management, 28, 2009, pp. 439-445.

[15] Mahnaz H, Mahnaz G, Naier A. Investigating the effect of economic value added on reporting of financial information, Online European Journal of Natural and Social Sciences. 2013, 2(3). p. 46.

[16] Socoliuc M, Grosu V. Financial Instruments Evaluation and the Difficulties of Economic and Financial Communication, Annals of "Constantin Brancusi" University of Targu-Jiu - utgjiu.ro; 2015.

[17] Tabără N, Dicu R-M. Indicatori de performanță în contextul reglementărilor contabile internaționale. Iaşi: Ed. Universității „Alexandru Ioan Cuza”; 2013, 372 p.

[18] Vasilescu L. Evaluarea performanței firmei pe baza indicatorilor financiari, Analele Universităţii „Constantin Brâncuşi”, Târgu Jiu, Seria Economie, nr. 3, 2011, 65 p. 